\title{
ANTIOXIDATIVE PROPERTIES OF MILK PROTEIN PREPARATIONS FERMENTED BY POLISH STRAINS OF LACTOBACILLUS HELVETICUS ${ }^{*}$
}

\author{
Katarzyna W. Skrzypczak ${ }^{1 \bowtie}$, Waldemar Z. Gustaw ${ }^{1}$, Ewa D. Jabłońska-Ryś ${ }^{1}$, \\ Monika Michalak-Majewska ${ }^{1}$, Aneta Sławińska ${ }^{1}$, Wojciech P. Radzki ${ }^{1}$, \\ Klaudia M. Gustaw², Adam D. Waśko² \\ ${ }^{1}$ Department of Fruits, Vegetables and Mushrooms Technology, University of Life Sciences in Lublin \\ Skromna 8, 20-704 Lublin, Poland \\ 2Department of Biotechnology, Human Nutrition and Food Commodity Science, University of Life Sciences in Lublin \\ Skromna 8, 20-704 Lublin, Poland
}

\begin{abstract}
Background. The increasing significance of food products containing substances with antioxidative activities is currently being observed. This is mainly due to the fact that pathogenic changes underlying some diseases are related to the carcinogenic effects of free radicals. Antioxidative compounds play an important role in supporting and enhancing the body's defense mechanisms, which is useful in preventing some civilization diseases. Unfortunately, it has been already proved that some synthetic antioxidants pose a potential risk in vivo. Therefore, antioxidant compounds derived from a natural source are extremely valuable. Milk is a source of biologically active precursors, which when enclosed in structural protein sequences are inactive. The hydrolysis process, involving bacterial proteolytic enzymes, might release biopeptides that act in various ways, including having antioxidant properties. The objective of this study was to determine the antioxidant properties of milk protein preparations fermented by Polish strains of $L$. helveticus. The research also focused on evaluating the dynamics of milk acidification by these strains and analyzing the textural properties of the skim milk fermented products obtained.

Material and methods. The research studied Polish strains of L. helveticus: B734, 141, T80 and T105, which have not yet been used industrially. The antioxidant properties of $1 \%(\mathrm{w} / \mathrm{v})$ solutions of milk protein preparations (skim milk powder, caseinoglycomacropeptide and $\alpha$-lactoalbumin) fermented by these strains were determined by neutralizing the free radicals with 2,2-diphenyl-1-picrylhydrazyl (DPPH*). Moreover, solutions of skim milk powder (SMP) fermented by the microorganisms being tested were analyzed on gel electrophoresis (SDS-PAGE). The dynamics of milk acidification by these microorganisms was also analyzed L. helveticus strains were used to prepare fermented regenerated skim milk products that were subjected to texture profile analysis (TPA) performed using a TA-XT2i (Stable Micro Systems, Godalming, UK).

Results. The results suggest that the antioxidant activity of fermented milk protein preparations depended on the type of milk protein preparation and was also related to the strain that conducted the fermentation process. The process of caseinoglycomacropeptide (CGMP) fermentation by DSMZ 20075, T105 and 141 significantly $(p<0.05)$ influenced the increase in the antioxidant activities of the protein preparation, the highest values of parameter were obtained in samples fermented by L. helveticus T105 $(64.82 \pm 0.013 \%)$, while in the case of $\alpha$-lactoalbumin $(\alpha$-la), the strongest free radical scavenging activity $(66.67 \pm 0.020 \%)$ was noted for unfermented samples (control).
\end{abstract}

\footnotetext{
* The research has been supported by Grant 2014/15/N/NZ9/04042 from the National Science Centre.
}

『katarzyna.skrzypczak@up.lublin.pl, phone +48 814623309 


\begin{abstract}
Conclusions. The greatest increase in DPPH scavenging activity ( $\%$ of inhibition) was noted for fermented SMP solutions. The highest values of the parameter measured were recorded for SMP fermented by the reference strain $(85.98 \pm 0.009 \%)$ and T80 $(81.66 \pm 0.013 \%)$. Strain T105 demonstrated the most desirable properties with respect to milk acidifying dynamic and texture properties of fermented skim milk products, while the reference strain (L. helveticus DSMZ 20075) and L. helveticus T80 seem to be more desirable in terms of the possibility of obtaining fermented protein preparations with the best antioxidant properties. The Polish strains analyzed here might find application in dairy products and also in developing functional food products. Furthermore, the preparations of milk protein that were fermented by the strains being tested may be a natural source dietary antioxidants.
\end{abstract}

Keywords: Lactobacillus helveticus, antioxidant activities, lactic acid fermentation

\title{
INTRODUCTION
}

Most of the fundamental pathogenic changes in diseases that affect a large part of the population are related to the carcinogenic effects of free radicals (FR) and reactive oxygen species (ROS) (Lobo et al., 2010). The consequences of exposing body cells to excessive FR are connected with oxidation of biomolecules and proteins, and DNA damage that leads to various mutations and cancer (Bhattacharyya et al., 2014; Rashad et al., 2011). Therefore, food products which contain substances with antioxidative activities play an important role in supporting and enhancing the body's defense mechanisms, which are crucial in preventing some diseases (Li et al., 2014; Urquiza-Martínez and Navarro, 2016). Unfortunately, it has been proved that some synthetic antioxidants pose a potential risk in vivo. Due to the fact that some of these synthetic agents can cause side effects, their addition to food products is restricted or even prohibited in some countries (Abubakr et al., 2012; Osuntoki and Korie, 2010). For this reason, antioxidant compounds derived from natural sources are extremely valuable.

Casein and whey proteins from bovine milk demonstrate high digestibility and a well-balanced amino acids profile. Furthermore, milk is also a valuable source of biologically active precursors, which closed in structural milk protein sequences are inactive. They might be released through the hydrolysis process involving bacterial proteolytic enzymes, which takes place e.g. during milk fermentation conducted by starter cultures (Dziuba et al., 2009; Griffiths and Tellez, 2013).

Lactobacillus helveticus are thermophilic, Gram-positive, non-staining rods belonging to lactic acid bacteria $(\mathrm{LAB})$ that exhibit the highest proteolytic activity influencing the formation of peptides with high antioxidative activity among all LAB (Hartmann and Meisel, 2007). Moreover, a number of the bacteria strains are used as starter cultures in the dairy industry, mainly due to their high tolerance to low $\mathrm{pH}$, rate of milk acidification and strong proteolytic properties (Nielsen et al., 2009).

Lactobacillus helveticus constitutes the dominant species in natural whey cultures used in the manufacture of traditional cheeses. Furthermore, some of the bacteria strains demonstrate a number of health-promoting properties that influence the increasing importance of L. helveticus in the production of functional food and nutraceutical products (Giraffa, 2014; Taverniti and Guglielmetti, 2012). However, L. helveticus exhibits intraspecific diversity. It has been suggested that environmental pressure affects the adaptation processes of wild bacterial strains to changes in natural habitat conditions. This might lead to some phenotype and genotype differences among strains. It has been shown that even biotypes isolated from the same niche are greatly various, and many of the technological properties indicated by the bacteria are strain-dependent (Gatti et al., 2014; Griffiths and Tellez, 2013; Rong et al., 2015). An analysis of the strains' variability may lead to the discovery of new bacteria strains with desirable characteristics exhibiting a wide range of potential applications in food biotechnology and food production, and therefore influencing greater food product safety.

One of the determinants of food spoilage is the oxidation process, while fermentation and components 
generated through this process might be a natural tool to solve some food safety problems (Osuntoki and Korie, 2010). Therefore, the objective of this study was to determine the antioxidant properties of selected preparations of milk protein that were fermented by Polish strains of $L$. helveticus. The dynamics of milk acidification by microorganisms was also analyzed. Within the framework of this research, L. helveticus strains were used to prepare fermented skim milk products that were subjected to further textural analysis.

\section{MATERIAL AND METHODS}

\section{Bacterial strains and growth conditions}

The strains of L. helveticus: B734, 141, T80 and T105 (isolated from Polish fermented milk products and kindly provided by the University of Warmia and Mazury in Olsztyn, Poland) were examined in this study. L. helveticus DSMZ 20075 (DSMZ, Braunschweig, Germany) was used as a reference strain. All strains were maintained in $15 \%$ glycerol stock and stored at $-80^{\circ} \mathrm{C}$.

Each bacterial strain was routinely cultured $(2 \% \mathrm{v} / \mathrm{v})$ in Man-Rogosa-Sharpe broth (BTL, Łódź, Poland) according to the conditions described by Waśko et al. (2014).

\section{Acidifying activity}

The overnight cell cultures were harvested by centrifugation $\left(10000 \times \mathrm{g} / 15 \mathrm{~min} / 4^{\circ} \mathrm{C}\right)$, washed twice with a sodium phosphate buffer $(50 \mathrm{mM}, \mathrm{pH} 7.0)$ and resuspended in the same buffer to the original sample volume. The bacterial cell suspensions obtained $\left(\mathrm{OD}_{600}=\right.$ 0.7 ) were used to inoculate samples of $13 \%$ regenerated skim milk (RSM) (OSM Krasnystaw, Poland), which had been pasteurized in a water bath $\left(80^{\circ} \mathrm{C} / 0 \mathrm{~min}\right)$ and cooled down up to $40^{\circ} \mathrm{C}$ before inoculation.
During incubation $\left(48 \mathrm{~h} / 42^{\circ} \mathrm{C}\right)$, the $\mathrm{pH}$ of samples was monitored every 6 hours $(\mathrm{pH}$ meter Hanna Instruments HI221). The measurements were done in triplicate (in sterile conditions). The dynamics of milk acidification by individual $L$. helveticus strain have been expressed as curves of $\mathrm{pH}$ changes during the incubation time.

\section{Preparation the fermented skim milk products}

The samples of $13 \%$ regenerated skim milk (RSM) (OSM Krasnystaw, Poland) were pasteurized $\left(80^{\circ} \mathrm{C} /\right.$ $30 \mathrm{~min}$ ), cooled down to $40^{\circ} \mathrm{C}$, inoculated with a $2 \%$ $(\mathrm{v} / \mathrm{v})$ individual strain suspension (inoculums prepared as described above) and poured in equal volumes $(40 \mathrm{ml})$ into sterile, identical packages and sealed. After fermentation $\left(42^{\circ} \mathrm{C} / 12 \mathrm{~h}\right)$, all samples were cooled down to $4^{\circ} \mathrm{C}$ and were stored in this temperature for another $12 \mathrm{~h}$ before further analysis.

\section{Antioxidant activity and soluble protein profile of milk protein preparation fermented by $L$. helveticus}

Aqueous solutions $(1 \% \mathrm{w} / \mathrm{v})$ of skim milk powder (SMP) (OSM Krasnystaw, Poland), $\alpha$-lactoalbumin $(\alpha-$ la) (Arla Food, Denmark) and caseinoglycomacropeptide (CGMP) (Arla Food, Denmark) were sterilized $\left(121^{\circ} \mathrm{C} / 15 \mathrm{~min}\right)$. The chemical compositions of protein preparations are shown in Table 1. After cooling (to $40^{\circ} \mathrm{C}$ ), the samples were inoculated with $2 \%(\mathrm{v} / \mathrm{v})$ of strain cell suspensions (inoculums prepared as described above) and fermented for $24 \mathrm{~h}$ at $37^{\circ} \mathrm{C}$ in anaerobic conditions. The antioxidant properties of the fermented products were determined by neutralizing the free radicals according to Osuntoki and Korie (2010) using 2,2-diphenyl-1-picrylhydrazyl (DPPH').

Table 1. Chemical composition of milk protein preparations, \%*

\begin{tabular}{lccccc}
\hline \multicolumn{1}{c}{ Preparate } & Protein & Lactose & Fat & Ash & Water \\
\hline SMP & 32.40 & 51.20 & 0.75 & - & 3.35 \\
$\alpha$-la & 88.00 & 10.00 & 2.00 & 5.00 & 5.50 \\
CGMP & 85.00 & 2.00 & 0.50 & 6.50 & 5.00 \\
\hline
\end{tabular}

*According manufacturers. 
The antioxidant activity was expressed as inhibition [\%] that was calculated from the following equation:

$$
\text { Inhibition, } \%=\left(A_{c}-A_{t}\right) \times 100 / A_{c}
$$

where:

$A_{c}-$ the absorbance $(\lambda=517 \mathrm{~nm})$ of the control sample $\left(\mathrm{DPPH}^{\cdot}\right.$ solution without protein fractions),

$A_{t}-$ the absorbance of the test sample (DPPH ${ }^{*}$ solution plus fermented or unfermented preparations).

The fermented samples of SMP obtained were then subjected to further analysis. The soluble protein content in the samples was determined by the Bradford method using bovine serum protein (BSA, Sigma, USA) as standard. The soluble protein profiles in the fermented and non-fermented samples (control) were analyzed through the sodium dodecyl sulfate polyacrilamide gel electrophoresis (SDS-PAGE) performed according to (Zhang et al., 2014).

\section{Texture profile analysis}

Texture profile analysis (TPA) was performed in order to determine and compare the textural characteristics of products obtained through fermentation of reconstituted skim milk (RSM) using the strains tested. The analysis was conducted using a TA-XT2i (Stable Micro Systems, Godalming, UK), according to the procedure outlined by Gustaw et al. (2016). The measurements included the values of the following parameters: hardness, springiness, gumminess, chewiness adhesiveness and cohesiveness.

\section{Statistical analysis}

Statistical analysis was conducted using the Statistica 8.0 (StatSoft, Poland) program. Analysis of variance (ANOVA) followed by Tukey's post hoc test was performed to determine significant differences $(p<0.05)$ among the average values of the parameters measured.

\section{RESULTS AND DISCUSSION}

It was confirmed that some protein preparations exhibit desirable health-promoting properties e.g. glycomacropeptide (GMP), a peptide derived from $\kappa$ - casein, shows various antibacterial and antithrombotic activities, while $\alpha$-lactalbumin ( $\alpha$-la) exhibits antiviral, antineoplastic activity (Zimecki and Artym, 2005). Moreover, bacterial proteolytic enzymes contribute to the formation of a wide range of bioactive peptides including sequences with antioxidative properties (Giraffa, 2014; Griffiths and Tellez, 2013; Taverniti and Guglielmetti, 2012; Widyastuti et al., 2014).

Due to the fact that strains of LAB might demonstrate antioxidative activity in various ways, indicating an individual constituent or describing one mechanism determining antioxidant activity is problematic and difficult (Virtanen et al., 2007). However, DPPH assay is considered to be a reliable method determining the ability of antioxidant to scavenge free radicals (Zha et al., 2009) and therefore it was used to evaluate the antioxidant ability of the samples.

The measurement of radical scavenging activity demonstrated that all tested milk protein preparations fermented by $L$. helveticus strains exhibited antioxidant properties (Table 2).

Unal and Akalm (2012), who analyzed the antioxidant activity of yoghurt supplemented with different types of milk protein, noticed different levels of scavenging activity depending on the protein preparation used. They suggested that the high scavenging activity of whey proteins is related to the properties of lactoferrin, $\beta$-lactoglobulin and $\alpha$-actalbumin. Varying degrees of antioxidant properties of fermented protein preparations were also reported in our study.

The fermented samples of CGMP exhibited free radical inhibition ranging from $33.34 \pm 0.049 \%$ (after the fermentation process conducted by T80) to 64.73 $\pm 0.013 \%$ (fermentation conducted by $\mathrm{T} 105$ ) and no statistically significant differences $(p<0.05)$ were observed between samples fermented by the reference strain $(63.00 \pm 0.005 \%)$ and L. helveticus 141 (63.40 $\pm 0.010 \%)$. Furthermore, fermentation of $\alpha$-la allows products with higher activity to free radical scavenging to be obtained (Table 2). The strongest DPPH scavenging activity was noted for unfermented samples $(66.67 \pm 0.020 \%)$, although there were no statistical differences $(p<0.05)$ between those control samples and 1-la fermented by the reference strain.

The process of fermentation SMP by Polish strains of $L$. helveticus significantly $(p<0.05)$ influenced the antioxidant activity of the protein preparation. 
Skrzypczak, K. W., Gustaw, W. Z., Jabłońska-Ryś, E. D., Michalak-Majewska, M., Sławińska, A., Radzki, W. P., Gustaw, K. M., Waśko, A. D. (2017). Antioxidative properties of milk protein preparations fermented by Polish strains of Lactobacillus helveticus. Acta Sci. Pol. Technol. Aliment., 16(2), 199-207. http://dx.doi.org/10.17306/J.AFS.2017.0479

Table 2. The radical scavenging activities (inhibition, \%) of milk protein preparations fermented by L. helveticus strains

\begin{tabular}{|c|c|c|c|c|}
\hline & & \multicolumn{3}{|c|}{ Protein preparation } \\
\hline & & $\alpha-1 \mathrm{a}$ & CGMP & SMP \\
\hline & Unfermented (control) & $66.67^{\mathrm{Aa}} \pm 0.020$ & $58.03^{\mathrm{Abc}} \pm 0.011$ & $42.71^{\mathrm{Bb}} \pm 0.015$ \\
\hline \multirow[t]{5}{*}{ L. helveticus strain } & B734 & $62.02^{\mathrm{Bb}} \pm 0.015$ & $57.21^{\mathrm{Cc}} \pm 0.020$ & $72.13^{\mathrm{Aab}} \pm 0.019$ \\
\hline & DSMZ 20075 & $66.58^{\mathrm{Ba}} \pm 0.032$ & $63.00^{\mathrm{Cb}} \pm 0.005$ & $85.98^{\mathrm{Aa}} \pm 0.009$ \\
\hline & 141 & $62.15^{\mathrm{Cb}} \pm 0.026$ & $63.40^{\mathrm{Bb}} \pm 0.010$ & $79.47^{\mathrm{Aa}} \pm 0.009$ \\
\hline & $\mathrm{T} 80$ & $51.52^{\mathrm{Bd}} \pm 0.028$ & $33.32^{\mathrm{Cd}} \pm 0.049$ & $81.66^{\mathrm{Aa}} \pm 0.013$ \\
\hline & $\mathrm{T} 105$ & $55.13^{\mathrm{Cc}} \pm 0.030$ & $64.82^{\mathrm{Ba}} \pm 0.013$ & $76.58^{\mathrm{Aa}} \pm 0.011$ \\
\hline
\end{tabular}

\footnotetext{
${ }^{\mathrm{a}-\mathrm{d}}$ Mean values (mean \pm standard deviation) with different letters in the same column indicate statistically significant differences $(p<0.05)$.

${ }^{\mathrm{A}-\mathrm{C}}$ Mean values with different letters in the same row indicate statistically significant differences $(p<0.05)$.
}

The greatest values of the parameter being measured were recorded after $24 \mathrm{~h}$ of fermentation by the reference strain $(85.98 \pm 0.009 \%)$ and T80 $(81.66 \pm 0.013 \%)$. However, there were no statistical differences $(p<0.05)$ between all fermented SMPs. A study conducted by (Elfahri et al., 2016) showed that extracts of milk fermented by $L$. helveticus 474 demonstrated the highest free radical (1,1-diphenyl-2-picrylhydrazyl) scavenging activity at $12 \mathrm{~h}$ of fermentation. Moreover, they also confirmed that those fermented products contained components with anti-colon cancer activity. Furthermore, research conducted by (Virtanen et al., 2007) suggests that free radical scavenging activity is dependent on the specific proteolytic enzymes of the bacteria strain rather than the proteolytic level of the fermented product. They also proved that antioxidative activity increases during fermentation, but is not directly associated with fermentation time.

The results indicating various antioxidative properties of fermented protein preparations, which depended on which $L$. helveticus strains were used are in accordance with the findings presented by Elfahri et al. (2014). Their research confirmed that peptides formed by different $L$. helveticus strains exhibit various antioxidative capacity and L. helveticus 1188 was distinguished as the greatest value of the parameter measured.

Skimmed milk powder (SMP) is commonly used to increase the content of dry matter of some dairy products, although results also suggest that SMP may have other desirable functions. The research findings show that SMP and regenerated skim milk (RSM) fermented using L. helveticus strains might influence the functional properties (antioxidant activity) of food, especially fermented dairy products.

The electrophoresis results (Fig. 1) indicate that the protein profile of SMP fermented by T105 differed

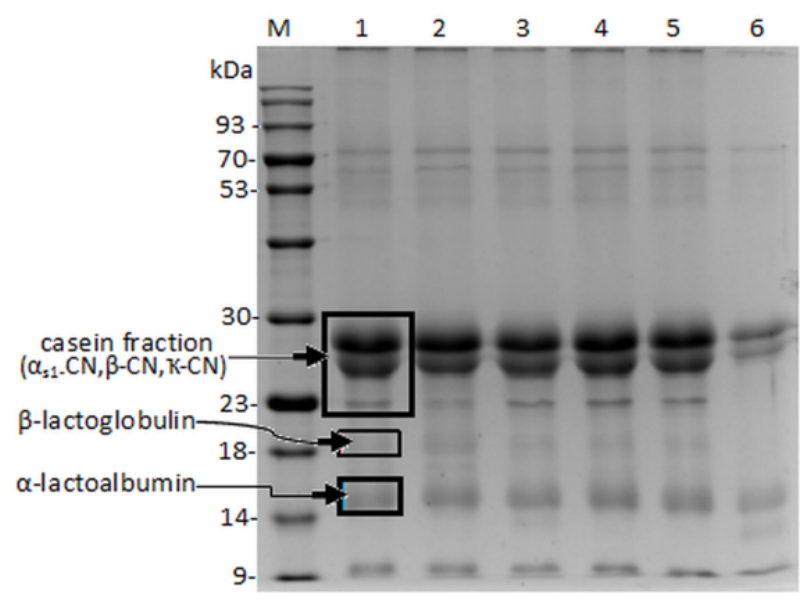

Fig. 1. The electrophoresis (SDS-PAGE) of skim milk powder (SMP) solutions: protein standard marker - line M, unfermented SMP (control) - line 1, SMP fermented by L. helveticus strains: B734 - line 2, DSMZ 20075 - line 3, 141 - line 4, T80 - line 5, T105 - line 
from other hydrolyzates. The variability refers mainly to the presence of products in the area between casein fractions and $\beta$-lactoglobulin (range of molecular mass from 23 to $18 \mathrm{kDa}$ ). It has been suggested that products in this range of molecular mass are substrates for bacterial proteases, which contribute to the generation of short peptides and amino acids (Ong et al., 2007). Furthermore, the hydrolyzates obtained using T105 also produced more low-molecular mass products (14-19 kDa). The reported variations might refer to Gilbert et al. (1997) and Oberg's (2002) findings confirming that some $L$. helveticus strains exhibit different cleavage patterns of milk protein, which suggests that some strains possess two different proteinase enzymes. Moreover, the study by Oberg (2002) indicates that the specificity of proteinases might be significantly different despite similar proteolytic activity. This might be one of the main factors reflecting the differences between fermented products obtained using the strains analyzed.

Lactobacillus helveticus is used in the manufacture of dairy products as starter cultures mainly due to the rate of reducing the $\mathrm{pH}$ value of milk, high tolerance acidity and strong protolytic activities. Strains of the species are able to decrease the $\mathrm{pH}$ value to 3.5 , while Lc. lactis and Streptococcus thermophilus inhibit their growth and ability to acidify at $\mathrm{pH}=4.3$ (Hebert et al., 2000).

The results obtained indicate that all Polish strains that were analyzed are able to decrease the $\mathrm{pH}$ of milk below 4.0 (Table 3 ), but $L$. helveticus T105 demonstrated differences $(p<0.05)$ in terms of the dynamics of milk acidification among all strains. This was the only strain which was able to reduce the $\mathrm{pH}$ value of milk up to 3.56 after $12 \mathrm{~h}$ of fermentation. Moreover, after $48 \mathrm{~h}$ the products obtained using this strain were distinguished $(p<0.05)$ by the lowest $\mathrm{pH}$ (3.13-0.012). Comparable results were obtained by Gandhi and Shah (2014), who fermented RSM (12\% w/v) with L. helveticus ASCC 953. After $12 \mathrm{~h}$ of fermentation the strain was able to decrease the $\mathrm{pH}$ value to $3.81 \pm 0.05$. This was the lowest $\mathrm{pH}$ value compared to other milk samples fermented by the following bacteria strains: Lactobacillus acidophilus CSCC 2400, L. delbrueckii ssp. bulgaricus ASCC 859 or Streptococcus thermophilus ASCC 1275.

These results indicate that the Polish strain of $L$. helveticus $\mathrm{T} 105$ exhibits strong acidifying ability, which is a valuable feature in terms of the possibility of using a starter culture in the manufacture of fermented dairy products.

Table 3. The dynamic of RSM acidification exhibited by L. helveticus strains

\begin{tabular}{|c|c|c|c|c|c|}
\hline \multirow{2}{*}{$\begin{array}{c}\text { Time of } \\
\text { fermentation, } \mathrm{h}\end{array}$} & \multicolumn{5}{|c|}{ L. helveticus strain } \\
\hline & $\mathrm{T} 105$ & 141 & B734 & $\mathrm{T} 80$ & DSMZ 20075 \\
\hline 0 & $6.58^{\mathrm{a}-0.006}$ & $6.60^{b}-0.006$ & $6.57^{\mathrm{a}-}-0.006$ & $6.62^{a}-0.006$ & $6.62^{\mathrm{b}}-0.006$ \\
\hline 6 & $4.79^{\mathrm{a}}-0.026$ & $5.99^{c}-0.006$ & $5.71^{\mathrm{b}}-0.006$ & $5.69^{\mathrm{b}}-0.021$ & $5.73^{\mathrm{b}}-0.006$ \\
\hline 12 & $3.56^{\mathrm{a}}-0.006$ & $5.18^{\mathrm{d}}-0.006$ & $5.47^{\mathrm{e}}-0.006$ & $4.80^{\mathrm{b}}-0.006$ & $5.07^{\mathrm{c}}-0.006$ \\
\hline 18 & $3.32^{\mathrm{a}}-0.015$ & $4.25^{b}-0.006$ & $4.72^{\mathrm{d}}-0.006$ & $4.62^{\mathrm{c}}-0.012$ & $4.76^{e}-0.006$ \\
\hline 24 & $3.27^{\mathrm{a}}-0.006$ & $4.42^{\mathrm{c}}-0.021$ & $4.66^{\mathrm{c}}-006$ & $4.08^{\mathrm{b}}-0.010$ & $4.10^{\mathrm{b}}-0.006$ \\
\hline 30 & $3.26^{\mathrm{a}}-0.010$ & $3.82^{b}-0.104$ & $4.16^{\mathrm{d}-0.006}$ & $4.01^{\mathrm{c}}-0.010$ & $3.88^{\mathrm{b}}-0.012$ \\
\hline 36 & $3.25^{\mathrm{a}}-0.006$ & $4.13^{\mathrm{d}}-0.006$ & $4.16^{\mathrm{e}}-0.006$ & $3.81^{\mathrm{d}}-0.006$ & $3.88^{\mathrm{c}}-0.012$ \\
\hline 42 & $3.24^{\mathrm{a}}-0.006$ & $3.70^{\mathrm{b}}-0.010$ & $3.90^{\mathrm{d}}-0.006$ & $3.81^{\mathrm{c}-}-0.015$ & $3.78^{\mathrm{c}}-0.010$ \\
\hline 48 & $3.13^{\mathrm{a}}-0.012$ & $4.01^{\mathrm{c}}-0.006$ & $3.79^{c}-0.010$ & $3.71^{\mathrm{b}}-0.006$ & $3.77^{c}-0.006$ \\
\hline
\end{tabular}

${ }^{\mathrm{a}-\mathrm{e}}$ Mean $\mathrm{pH}$ values (mean standard deviation $(\bar{x} \pm \mathrm{S} / \mathrm{SD}) ; n=3$ ) with different letters in the same column indicate statistically significant differences $(p<0.05)$. 
Skrzypczak, K. W., Gustaw, W. Z., Jabłońska-Ryś, E. D., Michalak-Majewska, M., Sławińska, A., Radzki, W. P., Gustaw, K. M., Waśko, A. D. (2017). Antioxidative properties of milk protein preparations fermented by Polish strains of Lactobacillus helveticus. Acta Sci. Pol. Technol. Aliment., 16(2), 199-207. http://dx.doi.org/10.17306/J.AFS.2017.0479

Table 4. The values of texture parameters of RSM fermented by L. helveticus strains

\begin{tabular}{lcccccc}
\hline \multicolumn{1}{c}{ Strain } & Hardness, N & Adhesiveness, $\mathrm{g} \cdot \mathrm{s}$ & Cohesiveness & Springiness & Gumminess & Chewiness \\
\hline T105 & $0.251^{\mathrm{a}} \pm 0.04$ & $0.753^{\mathrm{a}} \pm 0.41$ & $1.037^{\mathrm{a}} \pm 0.03$ & $1.037^{\mathrm{a}} \pm 0.42$ & $0.110^{\mathrm{a}} \pm 0.01$ & $0.107^{\mathrm{a}} \pm 0.06$ \\
B734 & $0.126^{\mathrm{e}} \pm 0.01$ & $0.090^{\mathrm{b}} \pm 0.12$ & $0.962^{\mathrm{d}} \pm 0.03$ & $0.962^{\mathrm{d}} \pm 0.08$ & $0.057^{\mathrm{d}} \pm 0.01$ & $0.055^{\mathrm{e}} \pm 0.01$ \\
T80 & $0.130^{\mathrm{d}} \pm 0.03$ & $0.081^{\mathrm{c}} \pm 0.08$ & $1.034^{\mathrm{b}} \pm 0.06$ & $1.035^{\mathrm{b}} \pm 0.26$ & $0.060^{\mathrm{cd}} \pm 0.01$ & $0.061^{\mathrm{d}} \pm 0.02$ \\
141 & $0.181^{\mathrm{b}} \pm 0.02$ & $0.068^{\mathrm{d}} \pm 0.50$ & $0.959^{\mathrm{e}} \pm 0.17$ & $0.959^{\mathrm{e}} \pm 0.47$ & $0.083^{\mathrm{b}} \pm 0.03$ & $0.084^{\mathrm{b}} \pm 0.04$ \\
DSMZ 20075 & $0.170^{\mathrm{c}} \pm 0.02$ & $0.057^{\mathrm{e}} \pm 0.09$ & $1.016^{\mathrm{c}} \pm 0.05$ & $1.015^{\mathrm{c}} \pm 0.27$ & $0.071^{\mathrm{c}} \pm 0.02$ & $0.069^{\mathrm{c}} \pm 0.04$ \\
\hline
\end{tabular}

${ }^{\mathrm{a}-\mathrm{e}}$ Mean values (mean \pm standard deviation) with different letters in the same column indicate statistically significant differences $(p<0.05)$.

The results of texture profile analysis (TPA) conducted on skim milk fermented by the individual strain of $L$. helveticus are shown in Table 4.

The highest values of hardness parameter were obtained for samples fermented by strain T105, while the lowest values were noted for products obtained by L. helveticus $\mathrm{B} 734$ and $\mathrm{T} 80$. The highest values for adhesiveness, springiness, gumminess and chewiness parameters were also noted for samples fermented by strain T105. Generally, acidic milky gels obtained using $L$. helveticus $\mathrm{T} 105$ were characterized by the most concise structure and constant consistency among all fermented RSM products.

These results highlight the need to develop indigenous Lactobacillus helveticus strains as starters in the food fermentation industry. They suggest that Polish strains analyzed here have technological potential (especially strain T105) and might find some application as starter cultures in the production of fermented dairy products. Moreover, the findings show that milk protein preparations fermented using $L$. helveticus strains might be a potential source of antioxidants that might provide an alternative to commonly applied synthetic additives.

Based on previous findings and scientific reports (Elfahri et al., 2016; Li et al., 2014; Power et al., 2013) it seems that the antioxidative properties of fermented milk protein preparations may enhance protection against adverse effects caused by the accumulation of reactive radicals in the organism and might be used to support the human body in reducing the negative oxidative effects. However, further study is required in order to explain the formation mechanisms of bioactive peptides with antioxidant properties during the fermentation process.

\section{CONCLUSION}

Among all the strains that were tested $L$ helveticus T105 exhibited the highest technological potential according to the results of acidifying activity assay and texture profile analysis of the fermentation products obtained. The reference strain (DSMZ 20075) and L. helveticus $\mathrm{T} 80$ seem to be more desirable in terms of the possibility of obtaining a preparation with high antioxidant properties. Moreover, the results indicate that the development of antioxidant activity in fermented milk protein preparation probably depends not only on the L. helveticus strain in the fermentation process, but also on the type of fermented protein preparation. The study's findings demonstrate that Polish strains might find application in the manufacture of dairy products, as well as in developing functional food products. Moreover, the preparations of milk protein that were fermented using $L$. helveticus strains may be a natural source containing dietary antioxidants.

\section{REFERENCES}

Abubakr, M. A. S., Hassan, Z., Eswai, G. S. M. (2012). Evaluation of antioxidant activity of skim milk hydrolysate fermented with lactic acid bacteria. Acta Biol. Malays., 1(3), 85-93. http://dx.doi.org/10.7593/abm/1.2.85

Bhattacharyya, A., Chattopadhyay, R., Mitra, S., Crowe, S. E. (2014). Oxidative stress: An essential factor in the pathogenesis of gastrointestinal mucosal diseases. 
Skrzypczak, K. W., Gustaw, W. Z., Jabłońska-Ryś, E. D., Michalak-Majewska, M., Sławińska, A., Radzki, W. P., Gustaw, K. M., Waśko, A. D. (2017). Antioxidative properties of milk protein preparations fermented by Polish strains of Lactobacillus helveticus. Acta Sci. Pol. Technol. Aliment., 16(2), 199-207. http://dx.doi.org/10.17306/J.AFS.2017.0479

Physiol. Rev., 94(2) 329-354. http://dx.doi.org/10.1152/ physrev.00040.2012

Dziuba, M., Dziuba, B., Iwaniak, A. (2009). Milk proteins as precursors of bioactive peptides. Acta Sci. Pol. Technol. Aliment., 8(1), 71-90.

Elfahri, K. R., Donkor, O. N., Vasiljevic, T. (2014). Potential of novel Lactobacillus helveticus strains and their cell wall bound proteases to release physiologically active peptides from milk proteins. Int. Dairy J., 38, 37-46. http://dx.doi.org/10.1016/j.idairyj.2014.03.010

Elfahri, K. R., Vasiljevic, T., Yeager, T., Donkor, O. N. (2016). Anti-colon cancer and antioxidant activities of bovine skim milk fermented by selected Lactobacillus helveticus strains. J. Dairy Sci., 99(1), 31-40. http:// dx.doi.org/10.3168/jds.2015-10160

Gandhi, A., Shah, N. P. (2014). Cell growth and proteolytic activity of Lactobacillus acidophilus, Lactobacillus helveticus, Lactobacillus delbrueckii ssp. bulgaricus, and Streptococcus thermophilus in milk as affected by supplementation with peptide fractions. Int. J. Food Sci. Nutr., 65(8), 937-941. http://dx.doi.org/10.3109/09637 486.2014.945154

Gatti, M., Bottari, B., Lazzi, C., Neviani, E., Mucchetti, G. (2014). Microbial evolution in raw-milk, long-ripend cheeses produced using undefined natural whey starters. J. Dairy Sci., 97(2), 573-591. http://dx.doi.org/10.3168/ jds.2013-7187

Gilbert, C., Blanc, B., Frot-Coutaz, J., Portalier, R., Atlan, D. (1997). Comparison of cell surface proteinase activities within the Lactobacillus genus. J. Dairy Res., 64(4), 561-571. http://dx.doi.org/10.1017/ S0022029997002355

Giraffa, G. (2014). Lactobacillus helveticus: importance in food and health. Front. Microbiol., 5, 338. http://dx.doi. org/10.3389/fmicb.2014.00338

Griffiths, M. W., Tellez, A. M. (2013). Lactobacillus helveticus: the proteolytic system. Front. Microbiol., 4, 30. http://dx.doi.org/10.3389/fmicb.2013.00030

Gustaw, W., Kozioł, J., Radzki, W., Skrzypczak, K., Michalak-Majewska, M., Sołowiej, B., ..., Jabłońska-Ryś, E. (2016). The effect of addition of selected milk protein preparations on the growth of Lactobacillus acidophilus and physicochemical properties of fermented milk. Acta Sci. Pol. Technol. Aliment., 15(1), 29-36. http://dx.doi. org/10.17306/J.AFS.2016.1.3

Hartmann, R., Meisel, H. (2007). Food-derived peptides with biological activity: from research to food applications. Curr. Opin. Biotechn., 18(2), 163-169. http:// dx.doi.org/10.1016/j.copbio.2007.01.013
Hebert, E. M., Raya, R. R., de Giori, G. S. (2000). Nutritional requirements and nitrogen-dependent regulation of proteinase activity of Lactobacillus helveticus CRL 1062. Appl. Envir. Microb., 66(12), 5316-5321. http:// dx.doi.org/10.1128/AEM.66.12.5316-5321.2000

Li, S., Chen, G., Zhang, Ch., Wu, M., Wu, S., Liu, Q. (2014). Research progress of natural antioxidants in foods for the treatment of diseases. Food Sci. Hum. Welln., 3(3-4), 110-116. http://dx.doi.org/10.1016/j.fshw.2014.11.002

Lobo, V., Patil, A., Phatak, A., Chandra, N. (2010). Free radicals, antioxidants and functional foods: Impact on human health. Pharm. Rev., 4(8), 118-126. http://dx.doi. org/10.4103/0973-7847.70902

Nielsen, M. S., Martinussen, T., Flambard, B., Sorensen, K. I., Otte, J. (2009). Peptide profiles and angiotensin-I-converting enzyme inhibitory activity of fermented milk products: Effect of bacterial strain, fermentation $\mathrm{pH}$, and storage time. Int. Dairy J., 19(3), 155-165. http://dx.doi.org/10.1016/j.idairyj.2008.10.003

Oberg, C. J., Broadbent, J. R., Strickland, M., McMahon, D. J. (2002). Diversity in specificity of the extracellular proteinases in Lactobacillus helveticus and Lactobacillus delbrueckii subsp. bulgaricus. Lett. Appl. Microbiol., 34(6), 455-460. http://dx.doi. org/10.1046/j.1472-765X.2002.01123.X

Ong, K. L., Cheung, B. M., Man, Y. B., Lau, C. P., Lam, K. S. (2007). Prevalence, awareness, treatment, and control of hypertension among United States adults, 1999-2004. Hypertension, 49(1), 69-75.

Osuntoki, A., Korie, I. (2010). Antioxidant activity whey from milk fermented with Lactobacillus species isolated from Nigerian fermented foods. Food Technol. Biotech., 48(4), 505-511.

Power, O., Jakeman, P., Fitzgerald, R. J. (2013). Antioxidative peptides: enzymatic production, in vitro and in vivo antioxidant activity and potential applications of milkderived antioxidative peptides. Amino Acids, 44(3), 797-820. http://dx.doi.org/10.1007/s00726-012-1393-9

Rashad, M., Abeer, E., Hala, M., Mohamed, U. (2011). Improvement of nutritional quality and antioxidant activities of yeast fermented soybean curd residue. Afr. J. Biotechn. 10(30), 5504-5513. http://dx.doi.org/10.5897/ AJB10.1658

Rong, J., Zheng, H., Liu, M., Hu, X., Wang, T., Zhang, X., Jin, F., Wang, L. (2015). Probiotic and anti-inflammatory attributes of an isolate Lactobacillus helveticus NS8 from Mongolian fermented koumiss. BMC Microbiol., 196(15), 1-11. http://dx.doi.org/10.1186/ s12866-015-0525-2 
Taverniti, V., Guglielmetti, S. (2012). Health-promoting properties of Lactobacillus helveticus. Front. Microbiol., 3, 392. http://dx.doi.org/10.3389/fmicb.2012.00392

Unal, G., Akalm, A. S. (2012). Antioxidant and angiotensinconverting enzyme inhibitory activity of yoghurt fortified with sodium calcium caseinate or whey protein concentrate. Dairy Sci. Techn., 92(6), 627-639. http:// dx.doi.org/10.1007/s13594-012-0082-5

Urquiza-Martínez, M. V., Navarro, B. F. (2016). Antioxidant capacity of food. Free Rad. Antiox., 6(1), 1-12. http:// dx.doi.org/10.5530/fra.2016.1.1

Virtanen, T., Pihlanto, A., Akkanen, S., Korhonen, H. (2007). Development of antioxidant activity in milk whey during fermentation with lactic acid bacteria. J. Appl. Microbiol., 102(1), 106-115. http://dx.doi. org/10.1111/j.1365-2672.2006.03072.x

Waśko, A., Szwajgier, D., Polak-Berecka, M. (2014). The role of ferulic acid esterase in the growth of Lactobacillus helveticus in the presence of phenolic acids and their derivatives. Eur. Food Res. Technol., 238(2), 299-236. http://dx.doi.org/10.1007/s00217-013-2107-6

Widyastuti, Y., Lisdiyanti, P., Tisnadjaja, D. (2014). Role of Lactobacillus helveticus on flavor formation in cheese: amino acid metabolism. Ann Bogor., 18(1), 1-11.

Zha, X. Q., Luo, J. P., Zhang, L., Hao, J. (2009). Antioxidant properties of different polysaccharides extracted with water and sodium hydroxide from rice bran. Food Sci. Biotechnol., 18, 449-455.

Zhang, L., Zhang, Y., Jiao, X., Luo, H., Li, L. Xin, Ch., ..., Ma, Ch. (2014). Technological characterization of lactic acid bacteria protease isolated from traditional Chinese fermented milk. J. Food Qual., 37, 395-402.

Zimecki, M., Artym, J. (2005). Therapeutic properties of proteins and peptides from colostrum and milk. Post. Hig. Med. Dośw., 59, 309-323 [in Polish; English abstract]. 